\title{
Challenges for humanization in the work of Nursing educators
}

\author{
Desafios para a humanização no trabalho do docente de enfermagem \\ Desafíos para la humanización en el trabajo de profesores de Enfermería
}

\author{
Magda Ribeiro de Castro ${ }^{a}$ \\ Kayo Henrique Jardel Feitosa Sousa ${ }^{b}$ \\ Flaviana Pereira Bastos Nascimento ${ }^{b, c}$ \\ Gisele Massante Peixoto Tracera ${ }^{\mathrm{b}, \mathrm{d}, \mathrm{e}}$ \\ Katerine Moraes dos Santos ${ }^{b, f, g}$ \\ Regina Célia Gollner Zeitoune ${ }^{b}$
}

\section{How to cite this article:}

Castro MR, Sousa KHJF, Nascimento FPB,

Tracera GMP, Santos KM, Zeitoune RCG.

Challenges for humanization in the work of Nursing educators. Rev Gaúcha Enferm. 2020;41:e20190390. doi: https://doi. org/10.1590/1983-1447.2020.20190390
Universidade Federal do Espírito Santo (UFES), Departamento de Enfermagem. Vitória, Espírito Santo, Brasil.

b Universidade Federal do Rio de Janeiro (UFRJ), Escola de Enfermagem Anna Nery. Rio de Janeiro, Rio de Janeiro, Brasil.

Associação Brasileira de Ensino Universitário (ABEU). Rio de Janeiro, Rio de Janeiro, Brasil.

Universidade Federal do Rio de Janeiro (UFRJ), Maternidade Escola. Rio de Janeiro, Rio de Janeiro, Brasil.

e Universidade do Estado do Rio de Janeiro (UERJ), Policlínica Piquet Carneiro. Rio de Janeiro, Rio de Janeiro, Brasil.

Universidade Federal do Rio de Janeiro (UFRJ), Instituto de Atenção à Saúde São Francisco de Assis Rio de Janeiro, Rio de Janeiro, Brasil.

${ }_{9}$ Universidade Federal do Estado do Rio de Janeiro (UNIRIO), Hospital Universitário Gaffrée \& Guinle, Rio de Janeiro, Rio de Janeiro, Brasil.

\section{ABSTRACT}

Objective: To discuss the challenges for humanization at work, from the perception of Nursing educators.

Method: A descriptive, exploratory, and qualitative research study conducted at a public university in Espirito Santo, with 19 Nursing educators who answered the semi-structured interview. Thematic analysis was used for data treatment, constituting two categories: interpersonal relationships and work organization.

Results: The challenges for humanization at work were based on relational issues and work overload. Regarding interpersonal relationships, lack of respect and dialog and relationship problems were highlighted. Regarding the organization of work, it encompassed issues related to the content of tasks, workload, excess of activities, and work pressures.

Conclusion: Relational elements and work organization are challenges for humanization, affecting the health of the educators and interfering in the organization of healthy and welcoming workspaces, contrary the National Humanization Policy.

Keywords: Work. Nursing. Faculty, nursing. Occupational health. Humanization of assistance.

\section{RESUMO}

Objetivo: Discutir os desafios para a humanização no trabalho, a partir da percepção de docentes de enfermagem.

Método: Pesquisa descritiva, exploratória, qualitativa realizada em uma universidade pública no Espírito Santo, com 19 docentes de enfermagem que responderam a entrevista semiestruturada. Utilizou-se a análise temática para o tratamento dos dados, constituindo duas categorias: relacionamento interpessoal e organização do trabalho.

Resultados: Os desafios para a humanização no trabalho foram pautados nas questões relacionais e sobrecarga laboral. Quanto às relações interpessoais, destacaram-se a falta de respeito e de diálogo e problemas de relacionamento. Referente à organização do trabalho, esta englobou questões relacionadas ao conteúdo das tarefas, carga horária, excesso de atividades e pressões laborais.

Conclusão: Os elementos relacionais e a organização do trabalho se apresentam como desafios para a humanização, repercutindo na saúde do docente e interferindo na organização de espaços de trabalho saudáveis e acolhedores, contrariando a Política Nacional de Humanização.

Palavras-chave: Trabalho. Enfermagem. Docentes de enfermagem. Saúde do trabalhador. Humanização da assistência.

\section{RESUMEN}

Objetivo: Discutir los desafíos para la humanización en el trabajo, desde la percepción de profesores de Enfermería.

Método: Investigación descriptiva, exploratoria y cualitativa realizada en una universidad pública de Espírito Santo, con 19 profesores de Enfermería que respondieron la entrevista semiestructurada. Se utilizó análisis temático para el tratamiento de datos, constituyendo dos categorías: relación interpersonal y organización del trabajo.

Resultados: Los desafíos para la humanización en el trabajo se basaron en problemas relacionales y sobrecarga de trabajo. En cuanto a las relaciones interpersonales, se destacaron la falta de respeto y de diálogo y los problemas de relación. En cuanto a la organización del trabajo, abarcó cuestiones relacionadas con el contenido de las tareas, la carga de trabajo, el exceso de actividades y las presiones laborales.

Conclusión: Los elementos relacionales y la organización del trabajo son desafíos para la humanización, que afectan la salud de los docentes e interfieren en la organización de espacios de trabajo saludables y acogedores, en contra la Política Nacional de Humanización.

Palabras clave: Trabajo. Enfermería. Docentes de enfermería. Salud laboral. Humanización de la atención. 


\section{口INTRODUCTION}

This study presents the challenges for humanization in the work of Nursing educators as its object. The interest in investigating this problem comes from the work experience of the researchers, where it was verified that, many times, the teaching work is not limited to the locus of work, involving diverse activities that require cognitive demand from this worker - through the capacity and ability to think, reason, reflect, study, and mediate the student's teaching-learning process - as well as physical demand, which can have a major impact on their physical and mental health, as well as on their professional performance.

The teaching work is permeated by the diversity and complexity of the activities, the versatility of the functions to be performed by the educators, and the demand for academic productivity, which often leads to increased competitiveness among peers, contributing to the fragility of interpersonal relationships, resulting in high intellectual, physical, and emotional demands.

In this context, the workers are submitted to an intense work rhythm, and, at times, exhausting due to the work overload imposed by the work organization, which impels them to work"outside" conventional hours and days. It is not uncommon to find that these workers have a reduction or lack of free time to rest, to have a moment of recreation, to practice physical activity, to experience leisure, and even to adopt healthy life habits, reaching the limit of negatively impacting on meeting their basic human needs, such as hydrating, eating, and resting properly. The teaching work process is invisible, which can compromise their psychic function, affectivity, and subjectivity (1).

Thus, studying the teaching work in the Nursing field, inserting humanization in this context, is a possibility to contribute to the health and work of these professionals, considering that the National Humanization Policy (Política Nacional de Humanização, PNH) chooses the labor process as one of the targets of its actions ${ }^{(2)}$.

The PNH is a Brazilian public policy that seeks to democratize relationships through the protagonism and autonomy of the individuals involved and to destabilize the instituted powers, by means of criticizing the modus operandi of the organization of intra-institutional power, based on hegemonic rationality ${ }^{(3)}$. In this sense, it is proposed to problematize the challenges that arise in the organization of the teaching work, in view of the university being the locus of institutionalized knowledge and powers.

In the review of the scientific production on humanization in the Nursing teaching work, there was lack of studies; in this perspective, this research is inserted in this gap and aims to contribute to these discussions.

Thinking about the challenges for the production of new healthier and more pleasurable forms of work for the Nursing educator stands out within the scope of the PNH as one of its guidelines that excel in valuing work and workers ${ }^{(4)}$. Therefore, it is necessary to put into practice the principles that guide the $\mathrm{PNH}$, concerning the autonomy and protagonism of the workers ${ }^{(2)}$, recovering and/or promoting their health and their work potential.

In this way, it is believed that work will produce positive effects for the individuals, in their personal and professional life, as well as in their health, since work developed based on the precepts of humanization can present favorable possibilities for the workers and the institutions.

The dynamics and scope of humanization is not limited to educational and health organizations; its practice can be consolidated in several organizational processes, as long as these aim to overcome technicality, with a view to "human, organizational, and social development", constituting itself as an "inclusive and transformative activity that aims to change institutional conditions in favor of collective well-being inside and outside work institutions"(5:8).

In addition to the aforementioned, a policy "that aggregates the innovations produced in several reformist experiences in health does not take place without tension and, in order to maintain itself, it needs to build many alliances"(6:18), understanding that healthy living conditions must be considered with the participation of the subjects involved in this process.

Thus, the pertinence of carrying out a modulation of this Policy was verified, elaborated in the scope of health that acts in a transversal way to the other policies, shifting it to the context of educational work, contributing to the areas of knowledge that encompass the Occupational Policy and Health, and corroborates the relevance of the theoretical point of view of this research and its originality.

It is understood that transversality allows openness for communication with the different fields, disciplines and actors, enabling the construction of collective actions, transforming the modes of relationship and communication between the subjects involved in this process, which will greatly contribute to the democratization of work relationships (2).

Thus, studying humanization in the work of the Nursing educator is also justified, as it understands that a humanized work context can enhance the worker, contributing to an appropriate, more efficient, and higher quality performance for teaching Nursing knowledge/practice. 
In this sense, it is believed that the precepts of the PNH can be applied in the work activity of Nursing educators, being feasible to discuss the PNH from the perspective of Occupational Health. Seeking to elucidate this modulation, this research aimed to discuss the challenges for humanization at work, from the perception of Nursing educators.

\section{METHOD}

This is a descriptive, exploratory and qualitative research study, carried out at a federal public university in southeastern Brazil that has two Nursing Departments (NDs).

At the time of data collection, the aforementioned Institution had a staff of 52 permanent educators. ND1 was composed of 35 permanent educators, working in the undergraduate program, in the Graduate Program in Nursing at the Professional Master's level, and in the Graduate Program in Collective Health at the Master's and Doctorate levels. ND2, created after the university's policy for inland-reach, and therefore more recent, had 17 nurse educators, all effective and active in the Nursing undergraduate course. In both, the educators worked in the coordination of disciplines, extension projects, and research studies, as well as in technical commissions in the department and at the university and different administrative activities.

The educators included in this study were those effective and in full exercise of the function, belonging to the ND, with academic training in Nursing, working in undergraduate and/or graduate courses, administrative positions or other activities; and the excluded educators were those who were away or on leave from their work activities during the data collection period.

Of the 27 eligible educators, 19 participated in the study, 14 belonging to ND1 and 05 to ND2. It is important to highlight that, during the research period, the institution in question went through the process of qualifying its teaching staff, with a considerable number of people who were away for doctorates or training, characterizing a methodological limitation.

Data was collected between October and December 2015. Semi-structured interviews, carried out by the main researcher in the ND or in a place of better convenience chosen by the participant, were used as a technique for collecting the information, being stopped when it was identified that the textual corpus was representative and that there was complementarity in the information. These were recorded with a mean duration of 64 minutes and transcribed in full, being later returned to the participants for checking, commenting and/or correction, seeking reliability of the data.
The treatment and interpretation of the information collected in the interviews were carried out through thematic content analysis ${ }^{(7)}$. Thus, the following steps were conducted: (01) pre-analysis, organization itself, corresponding to the transcription, re-reading, and ordering of the information; (02) exploration of the material, exhaustive and repeated reading of the interviews and coding, treating the data to turn them into meaningful units and capable of allowing for a representation of the content, aggregating them by similarity of ideas or phrases enunciated by the participants in nuclei of meaning; and (03) categorical analysis of the text, through the aggregation of information in thematic categories of analysis, interpreted in the light of the theoretical and bibliographic reference relevant to the theme under study.

The study was approved by the Research Ethics Committees of the institutions (proponent and co-participant), under Opinions No.871,863 and No.964,125, respectively. Data collection was initiated after such approvals and acceptance by the participants with subsequent signature of the Free and Informed Consent Form, leaving the participants with a copy of that form.

\section{RESULTS}

Among the characteristics of the sample, presented in Table 1, it was evidenced that 17 (89.5\%) participants were female, ten (52.6\%) were married, and eight (42.1\%) were aged between 28 and 37 years old, eight (42.1\%) with a degree in Nursing from 05 to 14 years, and nine (47.3\%) working as effective educators at the institution between 1 and 10 years. It was also observed that 15 (78.9\%) participants referred to previous experience as an educator and that 13 (68.4\%) had a PhD course.

It was verified that the Nursing educators worked in different work fronts, performing numerous academic activities that, many times, overlapped. For example, acting in undergraduate and graduate courses, extension projects, research studies, and administrative activities, with a mean [self-reported] workload of around 34 hours per week. In addition to the hours of on-site work at the university, the educators'reports reveal that their activities were also carried out in the home environment, during leisure hours, whether on weekends or holidays.

Concerning the educators' perception on humanization in their work, challenges were mentioned, aiming to guarantee humanization in the studied institution, the following nuclei of meaning being enunciated: tense, fragile, and conflicting relationships; the overlapping of personal interests over the collective; the contradiction between what is taught to the 
Table 1- Sociodemographic and work characterization of the study participants. Vitória, ES, Brazil, 2015 ( $n=19)$

\begin{tabular}{|c|c|c|}
\hline Characteristic & $\mathbf{n}$ & $\%$ \\
\hline \multicolumn{3}{|l|}{ Gender } \\
\hline Female & 17 & 89.5 \\
\hline Male & 2 & 10.5 \\
\hline \multicolumn{3}{|l|}{ Age } \\
\hline 28-37 years old & 8 & 42.1 \\
\hline 38-47 years old & 2 & 10.5 \\
\hline 48-57 years old & 7 & 36.9 \\
\hline $58-62$ years old & 2 & 10.5 \\
\hline \multicolumn{3}{|l|}{ Marital status } \\
\hline Married & 10 & 52.6 \\
\hline Single & 7 & 36.9 \\
\hline Divorced & 2 & 10.5 \\
\hline \multicolumn{3}{|l|}{ Nursing Training Time } \\
\hline $5-14$ years & 8 & 42.1 \\
\hline $15-24$ years & 2 & 10.5 \\
\hline 25-34 years & 4 & 21.1 \\
\hline 35-39 years & 5 & 23.3 \\
\hline \multicolumn{3}{|c|}{ Teaching Time at the Institution } \\
\hline Up to 1 year & 3 & 15.8 \\
\hline $1-10$ years & 9 & 47.3 \\
\hline $11-20$ years & 1 & 5.3 \\
\hline $21-30$ years & 3 & 15.8 \\
\hline $31-40$ years & 3 & 15.8 \\
\hline \multicolumn{3}{|c|}{ Previous Experience in Teaching } \\
\hline Yes & 15 & 78.9 \\
\hline No & 4 & 21.1 \\
\hline \multicolumn{3}{|l|}{ Academic Degree } \\
\hline PhD & 13 & 68.4 \\
\hline Master's degree & 6 & 31.6 \\
\hline \multicolumn{3}{|l|}{ Teaching Performance } \\
\hline $\mathrm{PhD}$ & 6 & 40.0 \\
\hline Master's degree & 11 & 57.9 \\
\hline Specialization & 6 & 40.0 \\
\hline Internship & 1 & 5.3 \\
\hline Graduation & 18 & 94.7 \\
\hline Extension & 12 & 63.2 \\
\hline Research & 14 & 73.7 \\
\hline Administrative & 16 & 84.2 \\
\hline
\end{tabular}

Source: Research data, 2015

Note: The "teaching performance" variable was evaluated with the option of multiple answers. Thus, the relative frequency was calculated for each stratum considering the total number of participants. 
student about relationships for a humanized practice and what is practiced by the educators with their peers; lack of sharing, dialog, and respect; the content of the tasks; the power relations; the overload of activities; lack of understanding of autonomy and protagonism; and the exhaustive workload. Thus, two categories of analysis were constituted: "Interpersonal Relationship" and "Work Organization".

In the "Interpersonal Relationship" category, interpersonal relationships, communication problems, and the lack of dialog were perceived as contributing to the non-humanization of the Nursing teaching work. In this context, the following statements stand out:

[...] there are some people [...] who don't listen to other people's opinions. [...] there's no humanization there. (Educator 1)

[...] I have a very comfortable environment today, but at the same time, I feel isolated and for me this is not humanization. (Educator 4)

[...] for me, relationships today [...] are a factor that weighs more so that this humanization process does not happen

[...]. (Educator 9)

[...] interpersonal relationships in my workplace are inflamed, complicated. (Educator 11)

[...] / think that in humanization, relationships [...] are the most important thing [...]. So, I think the institution needs to humanize itself [...]. This is very difficult, because we have a very ingrained culture ofyears of power, of power relations; it's very difficult [...]. (Educator 16)

[...] relationships are getting more and more strained [...] we work in an environment of many vanities, it's a bonfire of vanity [...]. (Educator 19)

The lack of respect and dialog at work stood out as impeding and/or limiting factors for humanization in the work of Nursing educators. It is therefore understood that both factors affect the field of work relationships, in which disrespectful attitudes were perceived as hindering elements for humanization in teaching, as mentioned by the following professionals:

[...] if a colleague doesn't respect the other, doesn't respect the work done by the other, this has very negative effects on our work environment and even on ourselves, to make us sick [...]. (Educator 3)

[...] human beings really need very little to be happy, they need to be respected. That's what this department lacks [...]. (Educator 10)
[...] so, this inability for you to open your mind, to respect the other, to try to listen to the other, I think it prevents a lot. (Educator 11)

[...] one thing that I think is negative in the department is this 'quarrelling.' (Educator 12)

[...] here you have people who don't respect each other, put their wishes in front of the other anyway [...] unfortunately I see that. (Educator 13)

[...] and disrespect, shouting, these things don't help much [...]. (Educator 18)

Impositions at work as limiting factors for humanization, many times, without the occurrence of dialog, characterize a challenge to be conquered. Educators emphasized the lack of dialog, as observed in the following statements:

[...] many times, I wasn't invited to participate in certain conversations [...] there's no dialog that favors humanization [...]. Imposition of ways of acting, imposition of conducts without dialog, without anything! Anyway, all this is certainly harmful. (Educator 5)

[...] imposing guidelines, imposing orders without opening to dialog. (Educator 8)

In the second category - "Work Organization" -, factors related to the work of the educator were mentioned, with emphasis on the workload, teaching activities, content of the tasks and pressures (challenges to achieve humanization), pointing to changes in style of life and illness. Characterizing the organization of the work of the Nursing educator as important, demonstrated by the following statements:

[...] you have to be inserted in a lot of things [...]. (Educator 2)

[...] / think that it can be a hindrance to the workload of the educator, because educators who have a very big workload, they ends up getting tired and start to have difficulties developing actions, and I think that this can make the work a little exhausting. (Educator 3)

[...] the excess of activities, which ends up leading to anxiety, stress [...] which for me is the biggest obstacle today [...]. (Educator 7 )

[...] / have no leisure. I don't have this! [...]. (Educator 15)

[...] pressures, they hinder productive work. Working under pressure is a very boring business and ends up wearing you out. (Educator 18) 
With regard to the content of the tasks developed by the educators as contributing to non-humanization at work, the following statements stand out:

[...] / think that sums up the work overload [...] we get overburden, run over the things we have to do [...]. (Educator6)

[...] and I have an excess of activities, a lot. Sometimes, I think that part of is my responsibility, because these are things I decided to take on [...]. (Educator 7)

[...] unfortunately I taught subjects that are not my domain, 'but I had to do it'! It frustrated me a lot. (Educator 14)

\section{DISCUSSION}

The sociodemographic and work profile of the participants revealed that the majority were young and married educators, with relative professional experience and a high number of extra-class activities, characterized, among them, as reading and correcting work outside working hours in the institution. These results are similar to those found in a number of studies ${ }^{(8-9)}$, in which the predominance of female, married, and young Nursing educators was observed.

As for the length of experience as an educator, the findings corroborate with what was identified in higher education Nursing workers in Chile ${ }^{(8)}$, and in this latter, the findings were similar regarding the training time.

A study carried out with university educators in Minas Gerais ${ }^{(9)}$ identified that university educators, who accumulated functions in postgraduate activities, presented stress due to work overload, negatively contributing to mental health, corroborating the results of this research, in which the educators accumulated many administrative, teaching, research, and extension activities, concomitantly.

Likewise, the findings of the study carried out in a medical school in Amsterdam ${ }^{(10)}$ ratify those of the research under analysis. The educators reported accumulating administrative, educational, and research functions, which led to an overlap of roles. With regard to the administrative activities, these were identified, among the working conditions, as those that most negatively impact the educators' health ${ }^{(11)}$.

In this sense, a study carried out with university educators in the Republic of Cameroon ${ }^{(12)}$ identified a high prevalence of the burnout syndrome among these educators, being significantly associated with precarious working conditions, dissatisfaction with the salary, feeling of strenuous work, conflicts with colleagues, and physical inactivity. There was also an association between the syndrome and fewer free weekends, less leisure time, and less time devoted to the family circle.

It is noteworthy that the work environment has a great influence on the well-being and performance of the faculty; therefore, adding work resources is more important than reducing work demands ${ }^{(10)}$. However, it is worth considering that having more resources at work does not necessarily mean guaranteeing workers' health.

By means of this research, it was observed that the activities of reading, studies, planning and correction of activities, among other activities, occur outside the institutional locus and after the regulated time for work, such as verified in other studies ${ }^{(13-14)}$. Often, these conditions occur due to the demands of the work organization as well as the job development in spaces that do not contribute to workers' health. Thus, aspects that contradict the organization of healthy and welcoming work spaces, which have a harmful impact on the health and well-being of the worker, are considered in this study as conditions that can contribute to the non-humanization of the work of Nursing educators.

In the conceptual framework, the term "non-humanization", mentioned by the participants in this research, is equivalent to the understanding of the word dehumanization $^{(24,15)}$, based on humanized work as the one that matches the assumptions of $\mathrm{PNH}$, reinforcing its elements and commitments. Thus, what was contrary to humanization and its precepts was considered as dehumanization in this study.

In this study, dehumanization was linked to issues related to tense and complicated relationships, present in the work context, encompassing lack of sharing and solidarity at work, contributing to work overload and to situations of disrespect for the workers inserted in this context, sometimes, with impositions on the educator without enabling dialog between peers.

With regard to these issues, a survey conducted with medical professors in Toronto ${ }^{(14)}$ investigated the predictors for job satisfaction, showing that it is twice as high in educators who classified teamwork as very good or excellent, pointing out the importance of interpersonal relationships in the work context and in job satisfaction.

Good interpersonal relationships were also mentioned in a survey carried out in Brazil(13) as a facilitator factor in the teaching work, allied to the identification with the profession, the professional pleasure coming from teaching, and the autonomy and flexibility for the development of their work activities. 
In this research, it was also evidenced that the work of the Nursing educator develops in the midst of overload and excess of activities, demands, absence of dialog, and disrespectful attitudes, problems that do not contribute to a healthy relationship between workers.

The intensification of the teaching work - as well as the forms of educational management based on the perspective of productivity, which are widespread in the country, establishing goals to be achieved to reach resources, including financial ones - was also identified in a study that depicts the process of precarious teaching work and its consequences for the health of the workers and for the quality of education (1), results that corroborate those of the study under analysis. Similar findings to those pointed out by another study ${ }^{(13)}$ highlighted the influence of the new configurations of the world of work for Nursing educators, which direct them to the need for versatility and multi-functionality in a work context, often precarious.

In view of the context presented by the participants of this study, who refer to the perception of non-humanization at work, it is pertinent to bring up elements of work organization, considering it to be a central issue. The activity performed and the mediating conditions between the prescribed and the real work, the processes and means used to carry out the activities, the demands and the misfortunes that need to be managed, put the health of this worker at risk, with reflexes that can be felt in the work process ${ }^{(16)}$.

Thus, an important reference to be incorporated in the reflection herein proposed concerns the organization of work that involves differences between the activity and the task. The first encompasses the way in which the processes are carried out, the human condition being essential for their execution; and the second involves the action itself to achieve a certain objective under established conditions, what is prescribed. Considering these definitions, it can be said that the teaching activity is imprescriptible; it's not limited to that, as it requires the relationship of man with the environment, in a particular and cultural way. Therefore, in the teaching work, what is prescribed must be considered, the tools, rules - either explicit or not - and the work collectives ${ }^{(16)}$.

Thus, the organization of work has an impact on the mental health of these individuals, which is evident in the statements that mention the presence of wear, anxiety, and stress, as well as other aspects that contribute to the psychic demobilization of the worker. A research conducted in Poland ${ }^{(17)}$ highlighted the occurrence of positive symptoms for burnout and decreased self-efficacy related to the negative assessment of factors in the workplace, with these organizational factors being related to participation in the decision-making process and team work.

Given this understanding, it is necessary to mobilize efforts so that the organization of work provides better conditions, so that the individuals react according to what defines the organization of their personality, and can develop their work in a more appropriate, creative, and effective way, actively mobilizing them and providing better health and subjective experiences of pleasure ${ }^{(18)}$. Regarding solidarity, it is highlighted that one of the values that guide the $\mathrm{PNH}$ is the establishment of solidary bonds ${ }^{(2)}$. Therefore, the non-existence of this bond contradicts the ideals of humanization. It is understood that the attitudes of individualism hinder the realization of positive relationships and the establishment of humanization among workers $^{(19)}$

Regarding the relational aspects widely mentioned by the educators, it was observed that these permeate the university space in general, not being the privilege of a department specifically.

It can be seen that the way the teaching work is organized in the studied institution seems to contradict those elements favorable to humanization, such as, for example, the possibility of the workers to use their subjectivity and potentiality at work ${ }^{(4)}$, as the reports state that their opinions are not always respected. Such problems contradict the precepts of the $\mathrm{PNH}$ that value collective participation in the work management process, aiming to foster workers' autonomy and protagonism ${ }^{(2)}$.

Therefore, the importance of the individuals in this process is considered, contributing to their visibility in the collective and in the decision-making processes of their work, allowing their voice to echo in this social, cultural, and historical space.

It is necessary to consider that, when the individuals work motivated, using their creativity and potential, their activities tend to generate much more adequate and efficient results, which allows a gain for the institution and for the workers themselves, with favorable repercussions, in the case of teaching, in the academic training of the student body.

Thus, it is essential to reflect on the hierarchical relationships that permeate the work of Nursing educators, considering that the new management models increasingly demand the active participation of the workers ${ }^{(4)}$. However, often in daily life, the effective exercise of the condition of being a subject in the work process is impaired, evidenced by the little governance in relation to their work. 
Regarding disrespect, it is considered that, in addition to being considered a violent occurrence, it erodes social relationships, going against the civility that is associated with respect for the rules of conviviality of members within an organized society ${ }^{(20)}$.

In the context examined, disrespect occurs within the scope of relationships. Therefore, in the calculation of work organization, being manifested through imposing work, it contributes to the weakening of interpersonal relationships, in addition to configuring a posture that goes against Ethics, and, above all, against the practices of good collective coexistence, hindering humanization at work.

Thus, it was verified that several aspects -even the ethical - compete for the perception of non-humanization in the Nursing teaching work, considering that the ethical attitude includes respect for the other and for the rights that the other possesses, constituting one of the commitments of the $\mathrm{PNH}$, enabling the practice of active listening and transversalization of the relationships ${ }^{(2)}$.

Disrespect was considered by the educators as an impediment to humanization at work, negatively impacting the work environment, and may even affect relationships and collaborate for acts of incivility ${ }^{(20)}$ or for other unethical behaviors that impede protagonism, autonomy, valuing the worker, and, therefore, humanization.

It is noteworthy that the absence of dialog mentioned by the educators contradicts the precepts of the $\mathrm{PNH}$, contributing to dehumanization at work, with lack of dialog being linked to the impositions and difficulties of sharing decisions, weakening the idea of collectivity in the group, and increasingly distancing humanization from this work environment. In this perspective, it is necessary to refer to the importance of the Expanded Clinic proposed in the PNH, which reinforces the construction of dialogical processes favorable to the interests, needs, and desires of the subjects who inhabit this relationship ${ }^{(2)}$.

It was understood that the statements presented relate to relational factors, since work needs to be an organized, participatory and democratic collective space, in which working involves relating, above all, based on respect and dialog.

Moving from the field of relationships, the participants stated the excessive workload, overload of activities and work pressures, which contribute to the educator's wear and tear and prevent and/or limit humanization in this work.

Such data were also found in other studies ${ }^{(1,10-14)}$, pointing to the need to restructure the organization of work so that it becomes more healthy, aiming to minimize the burden, the demand, and the pressure at work, and to encourage the effective participation of the educators in the decisions about their actions, respecting and dialoguing with all the participants involved in this process.

Thus, the participation of everyone in the humanization process is essential, since the ability to think constructive possibilities, to propose changes that transform reality, will depend on the human beings, subjects capable of transforming work processes, equally transforming themselves in that process.

\section{$\square$ CONCLUSION}

It was verified that elements of the work organization such as relational issues strongly permeated by vulnerability and fragility linked to the existence of disrespectful conducts can converge, directly or indirectly, to dehumanization in teaching.

Regarding the perception of the educators, constituting challenges and impediments to the achievement of humanization in their work, it was identified that the intensification of work contributes to the understanding of non-humanization, going against the organization of healthy and welcoming work spaces, with harmful repercussions on the health and well-being of the worker.

In the context studied, it was evidenced that the teaching work sometimes contradicts important precepts of humanization such as autonomy and protagonism of the subjects, democratization of work relations, worker participation, and presence of dialog, converging even to a disrespectful and unethical posture. So, how to decide something about someone excluded from the debate?

In fact, such issues do not contribute to a job that recovers and/or promotes the workers'health, much less humanization at work, since their participation in this process as active subjects of this construction is important.

As a contribution, the fact is pointed out that the educators have perceived the issues related to non-humanization in their work, which constitutes an important critical view for the worker's health process; therefore, the search for humanization at work must constitute a continuous movement, shared among all the workers and. therefore, it is a collective responsibility.

Thus, reflecting on the testimonies, converging to the referential landmarks of the National Policy for Humanization and Occupational Health as regards theoretical-political fields, in addition to contributing to the areas of knowledge, confirms the relevance of future research studies on humanization in the context of the health of the teaching worker. 
It is also believed in the relevance of expanding the discussion herein presented to other work contexts, expanding the reflection about the teaching work and the health of this essential worker in the training of future professional generations.

It can also be considered that this research pointed contributions to the practice from the possibility of providing subsidies, allowing referrals to reflect on interventions and changes in the daily work of the educators, aiming to favor the health and well-being of these workers, as well as to (re)think about the development of their work activities, consequently impacting on the quality of teaching.

A limitation of the study was the significant number of educators in the process of professional qualification at the time of data collection, reducing the number of participants. However, the study fulfilled its objective and brought a discussion of humanization in the teaching practice, looking at the challenges faced to do so, revealing the possibility of modulating the National Humanization Policy for the educational context.

\section{REFERENCES}

1. Gouvêa LAVN. Teachers' working conditions and illnesses on the agenda of a labor union. Saúde Debate. 2016;40(111):206-19. doi: https://doi. org/10.1590/0103-1104201611116

2. Ministério da Saúde (BR). Secretaria-Executiva. Núcleo Técnico da Política Nacional de Humanização. HumanizaSUs: Política Nacional de Humanização: a humanização como eixo norteador das práticas de atenção e gestão em todas as instâncias do SUS. Brasília (DF): Ministério da Saúde; 2004 [cited 2018 Feb 25]. Available from: http://bvsms.saude.gov.br/bvs/publicacoes/ humanizasus_2004.pdf.

3. Matias MCS, Verdi MIM, Finkler M. A dimensão ético-política da humanização e a formação de apoiadores institucionais. Trab Educ Saúde. 2016;14(1):55-75. doi: https://doi.org/10.1590/1981-7746-sip00095.

4. Ministério da Saúde (BR). Secretaria de Atenção à Saúde. Departamento de Ações Programáticas Estratégicas. HumanizaSUS: Programa de Formação em Saúde do Trabalhador. Brasília (DF): Ministério da Saúde; 2011 [cited 2018 Feb 25]. Available from: http://bvsms.saude.gov.br/bvs/publicacoes/programa_ formacao_saudetrabalhador.pdf.

5. Cortez PA, Zerbini T, Veiga HMS. Práticas humanizadas de gestão de pessoas e organização do trabalho: paraalém do positivismo edo dataísmo. Trab EducSaúde. 2019;17(3):e0021544. doi: https://doi.org/10.1590/1981-7746-sol00215

6. Martins (P, Luzio CA. HumanizaSUS policy: anchoring a ship in space. Interface (Botucatu). 2017;21(60):13-22. doi: https://doi. org/10.1590/1807-57622015.0614

7. Bardin L. Análise de conteúdo: Ed. rev ampl. Lisboa: Edições 70; 2011.
8. Parra Giordano D, Felli VEA. Work process of nursing professors. Rev Latino-Am Enfermagem. 2017;25:e2946. doi: https://doi. org/10.1590/1518-8345.1941.2946

9. Soares MB, Mafra SCT, Faria ER. A relação entre a carreira do magistério superior, suporte familiar e estresse ocupacional dos docentes da Universidade Federal de Viçosa-MG. Textos Contextos. 2018;17(2):321-34. doi: https://doi. org/10.15448/1677-9509.2018.2.24990

10. van den Berg JW, Verberg (PM, Berkhout JJ, Lombarts MJMH, Scherpbier AJJA, Jaarsma ADC. A qualitative interview study on the positive wellbeing of medical school faculty in their teaching role: job demands, job resources and role interaction. BMC Res Notes. 2015;8:401. doi: https://doi.org/10.1186\%2 Fs13104-015-1393-4

11. Pinto MJS, Pintor FA, Detta FP. Condições de trabalho que mais impactam na saúde dos docentes de enfermagem: revisão integrativa. Enferm Foco. 2017];8(3):51-5. doi: https://doi.org/10.21675/2357-707X.2017.v8.n3.1239

12. Ngalagou PTM, Assomo-Ndemba PB, Manga LJO, Ebolo HO, Ayina Ayina CN, Tanga MYL, et al. Burnout syndrome and associated factors among university teaching staff in Cameroon: effect of the practice of sport and physical activities and leisures. Encephale. 2018:45(2):101-6. doi: https://doi.org/10.1016/j. encep.2018.07.003

13. D'Oliveira CAFB, Almeida CM, Souza NVDO, Pires A, Madriaga LCV, Varella TCMML Teaching work of nursing and the impact on the health-disease process. J Res Fundam Care online. 2018;10(1):196-202. doi: https://doi.org/10.9789/21755361.2018.v10i1.196-202

14. Krueger P, White D, Meany C, Kwong J, Antao V, Kim F. Predictors of job satisfaction among academic family medicine faculty: findings from a faculty work-life and leadership survey. Can Fam Physician. 2017 [cited 2019 oct 11];63:177-85. Available from: https://www.ncbi.n/m.nih.gov/pmc/articles/ PMC5349738

15. Benedetto MAC, Gallian DMC. Narrativas de estudantes de Medicina e Enfermagem: currículo oculto e desumanização em saúde. Interface (Botucatu). 2018;22(67):1197-207. doi: https://doi.org/10.1590/1807-57622017.0218

16. Alves WF. A invisibilidade do trabalho real: 0 trabalho docente e as contribuições da ergonomia da atividade. Rev Bras Educ. 2018;33:e230089. doi: https://doi. org/10.1590/s1413-24782018230089

17. Pena L, Remoaldo P. Psicodinâmica do trabalho: um estudo sobre o prazer e o sofrimento no trabalho docente na Universidade Óscar Ribas. Saúde Soc. 2019;28(4):147-59. doi: https://doi.org/10.1590/s0104-12902019170487

18. Nowakowska I, Rasińska R, Głowacka MD. The influence of factors of work environment and burnout syndrome on self-efficacy of medical staff. Ann Agric Environ Med. 2016;23(2):304-9. doi: https://doi. org/10.5604/12321966.1203895

19. Martins JT, Galdino MJQ, Garanhani ML, Sammi KM, Trevisan GS. Humanization in the work process in the view of intensive care unit nurses. Cogitare Enferm. 2015;20(3):589-95. doi: https://doi.org/10.5380/ce.v20i3.41521

20. Almeida EAB, Holanda MJB. Atos de incivilidade: um comportamento cada vez mais frequente no ambiente escolar. Outras Palavras. 2016 [cited 2018 0ct 05];12(1):1-10. Available from: http://revista.faculdadeprojecao.edu.br/index. php/Projeca05/article/view/597 
Castro MR, Sousa KHJF, Nascimento FPB, Tracera GMP, Santos KM, Zeitoune RCG

\section{Acknowledgments:}

To the Coordination for the Improvement of Higher Level Personnel (Comissão de Aperfeiçoamento de Pessoal de Nivel Superior, (APES) for granting a Doctoral Scholarship to Kayo Henrique Jardel Feitosa Sousa (Process No. 88887.333968/2019-00) and financial aid for the agreement between the Federal University of Rio de Janeiro/Anna Nery Nursing School and the Federal University of Espírito Santo/Post-Graduate Program in Nursing for the achievement of a Doctorate in the Inter-Institutional Modality, of which this work is a product (Process No. 23038.009178/2012-36).

\section{- Corresponding author:}

Kayo Henrique Jardel Feitosa Sousa

E-mail: kayohenriquejardel@hotmail.com

\section{Associate editor:}

Dagmar Elaine Kaiser

\section{Editor-in-chief:}

Maria da Graça Oliveira Crossetti 